\title{
MIGRATORY THREATS TO NATIONAL SECURITY OF UKRAINE: CURRENT CHALLENGES AND WAYS OF REGULATION
}

\author{
Mychailo ROMANIUK ${ }^{1}$ \\ Vasyl Stefanyk Precarpathian National University, Ukraine \\ Zinaida SMUTCHAK ${ }^{2}$ \\ Kirovograd Flight Academy of the National Aviation University, Ukraine
}

\begin{abstract}
The purpose of the article is to disclose the migratory threats which are connected with external and mass internal inter-regional migrations, which are caused by the annexation of the Crimea and military aggression in Donbas by Russia. Methodological and practical aspects of improving the management of intensive interstate and inter-regional migratory processes, negative consequences of which threaten national security of the country because of hybrid war in Donbas, illegal migration, worsening of the demographic situation, departure of scientists and specialists abroad are described in the article too. The main strategic objective, which consists of maintenance of state sovereignty, territorial integrity of Ukraine, and also integration in European and migratory space, ensuring close to the world standards of quality and length of life, realization of rights and freedoms of citizens, is formulated. Actions and tasks of the state migratory policy, ways and methods of regulation of external migrations of the population are considered. Principal reasons of external migrations of population are identified and analysed. The inwardly-regional, interregional and intergovernmental migrations of population of Ukraine in the years of its state independence (19912014) are analyzed in details. The results of analysis showed that migratory activity goes down on inwardly-regional and interregional levels. Also intensity of exchange of population went down between the regions of country. At the same time Ukraine for years state independence through depopulation processes lost 6,5 million persons, and in the external migratory moving of population of loss made over 1 million persons. The problem of illegal external labour migration is considered. It is noted that illegal migration from Ukraine to the threats to national security in the Law of Ukraine "On the National Security of Ukraine" is not included, and a threat to national security posed by illegal migration from Ukraine state authorities and management of both central and local underestimated. Attention is accented on that adjusting of migratory processes at the macrolevel must become to the ponderable component of socio-economic policy of the state, and the measures of migratory policy consist of that to obtain organization of migratory space of country and take under effective state control those migratory processes that take place in it. Proposals concerning perspective and effective actions of the state migratory policy of Ukraine in regulating migratory movement of the population from the positions of national priorities and regional peculiarities, and also personal needs of migrants and prevention of migratory threats to national security of Ukraine are formulated. It is determined that the decisive role in the regulation of labour migration processes, as a whole in Ukraine and its regions, belonging to the management of social-economic factors, such as living conditions and employment of people who can change as a result of redistribution of the state budget, wage-fund, public forms of consumption.
\end{abstract}

Key words: external migrations, internal migrations, interregional migrations, forced mass internal migratory resettlements, interstate migrations, foreign labour migrations, migratory threats to national security, migratory challenges, state migration policy.

JEL Classification: J61, J60, J10, J69, F22, F52, J68

\section{Introduction}

Now the migration processes in Ukraine differently exert its influence in its demographic development, participation in the international division of labour entering the European and world markets, social and national security.
This fact is of particular relevance since Ukraine in June 2014 signed the Association Agreement with the EU.

Today the main strategic objective is to maintain state sovereignty and territorial integrity of Ukraine and integration into the European economic space and

\footnotetext{
Corresponding author:

${ }^{1}$ Department of Management and Marketing, Vasyl Stefanyk Precarpathian National University.

E-mail: romaniuk.md@gmail.com

${ }^{2}$ Department of Management, Economics and Law, Kirovograd Flight Academy of the National Aviation University.

E-mail: zinulechka@ukr.net
} 
migration, ensuring closer to international standards of quality and length of life, the rights and freedoms of citizens.

Analysis and consideration of current migration trends in our country in the context of Ukraine's participation in European and global migration space is regarded as one of the important factors in the formation of their own national policies. This problem directly and indirectly is in the plane of national security of Ukraine.

Today there is especially distinguished appearance in problem regions of Ukraine a considerable number of displaced persons due to the annexation of the Crimea by the Russian Federation, foreign military aggression of Donbas and military conflicts that are continuing in the Donetsk and Luhansk regions. It should be noted that because of these reasons, the most urgent problem for Ukraine was the rapid growth of internal (resettlement) migration and emigration.

From April 2014 - the beginning of hostilities in Donbas, from Donetsk and Luhansk regions moved according to the OUN more than 2 million people, among them $1 \mathrm{mln}$. 750 thousand people moved to other regions of Ukraine, and over 300 thousand people emigrated to Russia. Almost 25 thousand people came to Ukraine from the annexed Crimea. Most internally displaced persons from Donbas is located in the Donetsk region - 660 thousands, Luhansk - 249 thousand, Kharkiv - 2010 thousand, Kyiv - 123 thousand, Zaporizhzhia - 116 thousand, Dnipropetrovsk -76 thousand, Kyiv -48 thousand, Odesa 36 thousand people (State Statistics Service of Ukraine).

These data are close to the real as it is impossible to count exactly the terms of military operations and realization of anti-terror operation. The main reason that encouraged high intensity of migration of population in Ukraine is annexation of Crimea, the Donbas hostilities, terrorism and attacks on the territorial integrity and sovereignty.

Based on their geographical location and level of features and socio-economic development and the development of the labour market and wages in the country, Ukraine is an active participant in international economic processes and one of the largest countries - donors of workforce in Europe. In terms of social-economic crisis, the role of labour migration as a source of reducing tension in local labour markets significantly increases.

The rapid intensification of international mobility of Ukraine, which is the process of globalization and increase in the intensity of international migration, actualizes the problem - the regulation of migration processes, providing for them an organized, safe and non-conflict nature.

The purpose of the article consists in research of modern challenges and threats that entailed the mass interregional and intergovernmental migratory transferring of population to the separate regions of Ukraine, general methodological going near the study of threats of modern migratory processes to national safety of country in theoretical and practical aspects and realization of measures of public migratory policy in relation to their warning and solution.

\section{Model and results}

In the Conception of public migratory policy of Ukraine it is marked, that it is sent to providing of effective state administration, conditioning migratory processes for steady demographic and socio-economic development of the state, increase of national strength security by prevention of origin of out-of-control migratory processes and liquidation of their consequences, concordance of national legislation in the field of migration with international standards, strengthening of social and legal defence of citizens of Ukraine, that live or work abroad, inhibition of principle of defence interest of Ukraine, and also that now threat national safety of Ukraine: illegal migration; intensifying of demographic crisis; departure out of Ukraine of scientists, specialists, skilled labour force (The decree of the President of Ukraine № 622, 2011).

Acceptance of important laws and innovations of public migratory policy grounds to assert that basic incentive reason of such actions was conditioned by an external factor and, in particular, reformation of migratory sphere is notedly activated since on a summit Ukraine - EU in November in 2010 to Ukraine was given the Plan of operating under liberalization of visa regime (Visa-free dialogue between Ukraine and the EU. Action plan on liberalization of visa regime).

For years of state independence in the period of economy reformation and transformation of all social-economic system, and also in connection with democratization of public life, economic crisis and falling of standards of life of swingeing majority of population of country character, volumes, composition and orientation of internal and external migratory streams, tested substantial changes and purchased a new value.

These changes are that there is reduced to a minimum a volume of daily flows of labour circular migration virtually ceased massive outflow of rural residents to cities, but instead there is a partial reorientation of migration flows of population from urban areas to rural areas, tenfold increased volumes of seasonal labour migration and external labour trips abroad.

Complex and often interrelated problems of external migration of the population of Ukraine as a whole and its regions in particular. During the years of state independence, there are three main periods of international migration movements of population: 1991-1993 years; 1994-2004 years; 2005-2014 years. Before and during the collapse of the USSR (1989-1991 years), and in the early years of statehood of Ukraine (1991-1993) to the Ukraine from Russia, Kazakhstan, Uzbekistan and other countries of UIS came 2,4 million persons, some of which were as immigrants because of the job, and representatives and descendants of deported peoples, and persons who were persecuted, dispossessed, and political prisoners.

Deep and permanent public changes in the walk of life of former Soviet Union were accompanied by expansion of processes of population moving through international 
borders often forcedly as a result of violence and threats. These migratory moving overcame 9 million persons and after these volumes in Europe it were the most shell migratory processes from the times of the World War II. At the same time over 2 million forced migrants from Donbas in 2014-2015 are most migratory migrants in Europe at the beginning XXI of century. As it is known to principal reasons of external migrations of population belong:

1) armed conflicts;

2) pursuits on an ethnic sign;

3) violations of human rights;

4) economic difficulties;

5) ecocatastrophes;

6) insolvency of governments to put right the deserving standard of living.

Only officially by the state on beginning in 2013 in countriesrecipients, where was most of Ukrainian labour migrants (over 1 million Ukrainians) there are, in particular, 208,8 thousands in Italy, 159,3 thousands in Germany; in Russia 126,4 thousands; in Czech Republic - 116,4 thousands; in Israel - 97,6 thousands, in Spain - 77,2 thousands, in the USA - 59,9 thousands, in Greece - 50,1 thousands, in Portugal - 48,0 thousands, in Canada - 43,0 thousand citizens of Ukraine, that live on territory of these countries officially (Vidyakina, Stakanov, 2011).
According to the data of the International organization of labour in 2012 the amount of Ukrainian labour migrants was almost 6 million persons; among them about $50 \%$ are young people under age 35 .

There is not long-term strategy of development of rural territories in Ukraine; accordingly, as a result, we look after the problems of migration in the country. As many villages fall into a decay, and even just disappear, a working seating capacity diminishes, and a salary remains extraordinarily subzero, people do not see possibility and prospect in a village. Such negative prospect makes the rural population to migrate to the cities or abroad in search of work. It should be noted that during 1995-2010 from the region of Carpathians (Lviv, Ivano-Frankivsk, Zakarpattia and Chernivtsi) annually duration of people worked abroad from six months to one year is about 300-500 thousand persons, the majority of them were from rural locality.

By the state on the end of 2013 one third of population of Ukraine lived in the rural settlements of Ukraine (31,4\% from the general amount of population). From 1993 the quantity of rural population annually grew short on 132 thousand and reductions of this index of persons is taking place making progress rates including through emigration. For 2010-2012 the quantity of rural population diminished almost on 100 thousand persons.

Table 1

Migrations of population of Ukraine in the years of state independence (1991-2014), persons

\begin{tabular}{|c|c|c|c|c|c|c|}
\hline \multirow{4}{*}{ Years } & \multicolumn{6}{|c|}{ Volumes of gross migration } \\
\hline & \multirow{3}{*}{ inwardly-regional } & \multirow{3}{*}{ interregional } & \multicolumn{4}{|c|}{ intergovernmental } \\
\hline & & & \multirow{2}{*}{ general volume } & \multicolumn{2}{|c|}{ including } & \multirow{2}{*}{ migratory balance } \\
\hline & & & & arrived & left & \\
\hline 1991 & 1188374 & 740622 & 800817 & 490597 & 310220 & 180377 \\
\hline 1992 & 1055036 & 667095 & 814356 & 538205 & 276151 & 262054 \\
\hline 1993 & 1021114 & 670670 & 634851 & 341192 & 293659 & 47833 \\
\hline 1994 & 893210 & 607611 & 515717 & 187392 & 328325 & -140933 \\
\hline 1995 & 839188 & 607260 & 422976 & 166551 & 256425 & -89874 \\
\hline 1996 & 858126 & 615536 & 376262 & 129538 & 246724 & -117186 \\
\hline 1997 & 846094 & 583678 & 299244 & 108559 & 190685 & -82126 \\
\hline 1998 & 894582 & 585083 & 221096 & 71810 & 149286 & -77476 \\
\hline 1999 & 875348 & 528576 & 176383 & 65794 & 110589 & -44795 \\
\hline 2000 & 461880 & 274861 & 154000 & 53700 & 100300 & -46600 \\
\hline 2002 & 450084 & 267448 & 118737 & 42473 & 76264 & -33791 \\
\hline 2003 & 443231 & 279313 & 103188 & 39489 & 63699 & -24210 \\
\hline 2004 & 445663 & 295149 & 84749 & 38567 & 46182 & -7615 \\
\hline 2005 & 439269 & 284373 & 74977 & 39980 & 34997 & 4583 \\
\hline 2006 & 440898 & 280757 & 74209 & 44227 & 29982 & 14245 \\
\hline 2007 & 435844 & 275941 & 76176 & 46507 & 29669 & 16838 \\
\hline 2008 & 407507 & 265960 & 59725 & 37323 & 22402 & 14921 \\
\hline 2009 & 367104 & 242798 & 52387 & 32917 & 19470 & 13447 \\
\hline 2010 & 394954 & 257685 & 45487 & 30810 & 14677 & 16133 \\
\hline 2011 & 379542 & 258171 & 46272 & 31684 & 14588 & 17096 \\
\hline 2012 & 377590 & 272275 & 90878 & 76361 & 14517 & 61844 \\
\hline 2013 & 360119 & 261723 & 76287 & 54100 & 22187 & 31913 \\
\hline 2014 & 273752 & 211106 & 64297 & 42698 & 21599 & 21099 \\
\hline In all & 14148509 & 9333691 & 5383071 & 2710474 & 2672597 & 37777 \\
\hline
\end{tabular}

Source: it is expected from data of the State Statistics Service of Ukraine 
Annually about 50 thousand peasants drive out abroad, $80,5 \%$ among them are young people and women.

In 2012 Ukraine was the fifth, after Turkey, Morocco, Albania and China, by a quantity of the group citizens of the third countries that lived on territory of the EU. Rating of Ukraine by part of emigrants was the first in Poland and Czech Republic, second place - in Russian Federation, Slovakia and Hungary, third place - in Estonia, fourth place - in Greece and Italy. In ten countries the quantity of Ukrainian labour migrants exceeded 100 thousand persons (State Statistics Service of Ukraine).

Actuality of the problems related to the mass intergovernmental migratory processes, most increases on a background of general demographic crisis that overcame Ukraine, beginning from 1991, and that entailed the crisis of migration largely, that in modern terms shows up in reduction in intensity of migrations in the middle of areas, considerably megascopic after a military conflict in Donbas at the interregional level and by the intensive streams of foreign labour migrants. The detailed analysis of inwardly-regional, interregional and intergovernmental migrations of population of Ukraine in the years of its state independence (1991-2014) is shown in a table 1.

Migratory activity goes down at inwardly-regional and interregional levels. Yes, if in 1991 within the limits of areas of country 594,2 thousand persons changed a residence, then in 2000 - 461,9 thousands, in 2007 - 435,8 thousand persons, in 2014 - only 273,7 thousand persons (by $59 \%$ less). Also intensity of exchange of population went down between the regions of country: on a permanent residence to other regions in 1991 there are 354,8 thousand persons left, and 385,8 thousand persons arrived, in 2000 these indexes presented 274,9 thousand persons in relation to arrive and drop-out, in 2007 is 276,0 thousand persons, and in 2014 year it is 211,1 thousand persons (by $38 \%$ less).

In a period from 1994 to 2004 years negative balance of external migration, that was almost 100 thousand persons annually, took place in Ukraine, and beginning from the year positive migratory balance that for period 20052014 presented 212,8 thousand persons takes place in external migrations of population of Ukraine. At the same time Ukraine for years of state independence through depopulation processes lost 6,5 million persons, and in the external migratory moving of population the loss was over 1 million persons.

Among 2,7 million persons a drop-out from Ukraine in the period of 1992-2012 years on a permanent residence to other countries of person with higher education laid down to $23,5 \%$. According to researches of International organization from migration and the age-related structure of the Ukrainian emigrants after five age-related groups have such kind: migrants in age $15-19$ - 3\%; 20-24 - 15\%; 25-34 - 34\%; 35-44 - 31\%; 45 and older $-17 \%$. Most of migrants from Ukraine are persons with the complete secondary and middle special education (48\%), so they are graduating students of high general schools, gymnasiums, lyceums, schools and colleges, people with base higher education (24\%) are graduating students of higher educational establishments with an educationally-qualifying level "bachelor", and also persons with complete higher education (18\%) are graduating students of higher educational establishments with an educationally-qualifying level "specialist" and master's degree (Datsko, 2014).

As for illegal foreign labour migration from Ukraine it is much higher. Foreign employers are advantageous to deal with illegal migrant workers, for persons who arrived in the country to earnings on illegal grounds there is a legal and social protection.

Moreover they are forced to accept any job - seasonal, difficult and dangerous, the rates set by them is much lower than citizens of the country. Foreign migrant workers from Ukraine in many countries are forced to work extended working hours and for hazardous working conditions, have limited or no access to health care and social security, protected against low wages, occupational injuries, diseases.

This problem requires urgent solution. Ukraine, as it provided by the part three of the Article 25 of the Constitution of Ukraine, guarantees care and protection to its citizens who are abroad. A similar provision is contained in the Article 8 of the Law of Ukraine "On Citizenship of Ukraine". It aims to provide the legal implementation of this constitutional provision.

The Law of Ukraine "On the National Security of Ukraine" to the main real and potential threats to national security of Ukraine ascribed: illegal migration (in the defense sector and security of the state border of Ukraine) and the outflow of scholars, professionals, skilled labour from Ukraine (in social and humanitarian areas). Illegal migration from Ukraine is not included to threats to national security and a threat to national security from illegal labour migration from Ukraine by state authorities and management of both central and local is underestimated.

And that is why adjusting of migratory processes at the macrolevel must become the ponderable constituent of social-economic policy of the state. Task in relation to a management migration, especially its external forms, consists not in that how to erect barriers through the system of administratively-restrictive measures that does not give possibility to get migrants to the developed countries, but how on the basis of observance of human rights and humane principles to manage the migratory streams of population, in particular, permanent and labour migrants taking into account interests of the state, host countries and regions (Malinovska, 2011).

\section{Findings}

The measures of migratory politics consist in that, how to obtain arrangement of migratory space of country and take those migratory processes taking place under effective state control.

Among basic, these tasks and measures in modern terms are the following: 
1) resettlement and employment of forced migrants from the areas of Donbas and Crimea;

2 ) to activate a voice process in relation to entering into contracts about mutual employment of citizens and their social defence with countries where the amount of labour migrants - citizens of Ukraine - is the biggest;

3 ) to assist the acceleration of making alteration to the agreements about a collaboration in the field of labour migration and social defence of labour migrants;

4) to realize measures in relation to the acceptance of projects of agreements that regulate motion of labour force with the countries of the EU;

5) to prepare the complex government program of adjusting of migratory processes with clear distribution of plenary powers and duties of central executive and local self-government bodies;

6) to take measures for reduction in scales of illegal labour migration of population outside the country; to conduct work in relation to the input of the analytical accounting with the aim of realization of control after a return to Ukraine of citizens, tourist services appeared;

7) to create the effective mechanisms of legalization of profits of citizens, that work abroad: to work out the mechanism of creation of favourable terms for translation to Ukraine of standard of labour migrants - citizens of Ukraine;

8 ) to study the system of taxation of labour migrants of other countries and ration tax of profits of labour migrants treatment - citizens of Ukraine;

9) to carry out practical measures on the settlement of educational migration (presently over 60 thousand Ukrainian students are studying abroad and so much foreigners are studying in Ukraine) on three levels: state, regional and even institutions of higher education both with countries-donors and with countries-competitors in the market of educational services.

10) to develop the mechanisms of counteraction of the negative migratory tendencies of creative and, especially, persons-innovators that can have destructive influence on social-economic development of separate territories and state as a whole (Romanjuk, 1999).

\section{Conclusions}

Today the special actuality have distinguished problems regarding the implementation of measures for the construction and employment of forced migrants from the annexed Crimea, Donetsk and Luhansk regions covered by hybrid war, support of Ukrainians living in the CIS countries, Baltic States and abroad, regulating the status of the CrimeanTatar people, cooperation with international organizations in countering and combating illegal immigration, border management, bringing Ukrainian migration legislation in line with international norms and principles of migration, settlement of intense flows of labour migration, social and legal defence of Ukrainian citizens working abroad and prevent the outflow of intellectual capacity.

The decisive role in the regulation of labour migration processes as a whole in Ukraine and its regions belongs to the management of social-economic factors, such as living conditions and employment of people who can change as a result of redistribution of the state budget wage-fund, public forms of consumption. Under current conditions, migration policy should very carefully monitor migration processes and their current trends and events, respond quickly to change and control them to subordinate national and regional interests and personal interests of migrants and generally promote national security of Ukraine.

\section{References}

Datsko, O. (2014). Influence of international migration and strengthening of threat to economic security of the country. Problems of external migration of Ukraine and other post-Soviet states: materials of round table - Lviv, Spolom, p. 25-29.

Kovalyk, I. (2011). Principles and consequences of international labor force migration for Ukraine, Strategy of development of Ukraine, issue 2, p. 278.

Malinovska, O. (2011). Labour migration: social consequences and ways of reaction - Kyiv, NISS, 40 p.

Malinovska, O. (2002). Management of migration: some conclusions from the European experience. Science issues UAPA, issue 2, p. 446-453.

On the concept of state migration policy (2011). The decree of the President of Ukraine № 622/2011. Retrieved from: http: // zakon2.rada.gov.ua/laws/show/622/2011

Organisation of Migration. Retrieved from: http://iom.org.ua/ua/

Prybytkova, I. (2011). Security of documents and migration policy: conclusions and recommendations of the international working groups for Ukraine - Kyiv, Europe without barriers, p. 9-30.

Romanjuk, M. (1999). Migration of the population of Ukraine: national priorities and regional differentiation regulation of the mechanism of regulation. Economy of Ukraine, issue 9, p. 38-44.

Romanjuk, M. (2009). Migration determinants of national security of Ukraine: theoretical and methodological, and practical aspects. Demography and social economy, issue 1 (11), p. 50-60.

State Statistics Service of Ukraine. Retrieved from: www.ukrstat.gov.ua

Vidyakina, M., Stakanov, G. (2011). Labour migration from Ukraine to the EU macroeconomic dimension - Kyiv, SSC, $196 \mathrm{p}$.

Visa-free dialogue between Ukraine and the EU. Action plan on liberalization of visa regime. Retrieved from:

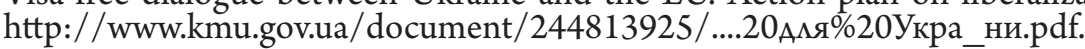




\section{Михайло РОМАНЮК, Зинаида СМУТЧАК}

МИГРАЦИОННЫЕ УГРОЗЫ НАЦИОНАЛЬНОЙ БЕЗОПАСНОСТИ УКРАИНЫ: СОВРЕМЕННЫЕ ВЫЗОВЫ, ПУТИ УРЕГУЛИРОВАНИЯ

Аннотация. Целью работы является исследование миграционных угроз, связанных с внешними и массовыми внутренними межрегиональными миграциями, вызванными аннексией Крыма и военной агрессией России на Донбассе. Также раскрыты методологические и практические аспекты усовершенствования управления интенсивными межгосударственными и межрегиональными миграционными процессами, негативные последствия которых несут в себе угрозы национальной безопасности страны из-за гибридной войны на Донбассе, нелегальной миграции, обострения демографической ситуации, отъезда за пределы страны ученых, специалистов. Сформулировано основное стратегическое задание, которое состоит в сохранении государственного суверенитета, территориальной целостности Украины, а также интеграции в европейское и миграционное пространство, обеспечении приближенных к мировым стандартам качества и продолжительности жизни, реализации прав и свобод граждан. Рассмотрены мероприятия и задания государственной миграционной политики, пути и методы регулирования внешних миграций населения. Определены и проанализированы основные причины внешних миграций населения. Проведен детальный анализ внутрирегиональных, межрегиональных и межгосударственных миграций населения Украины в годы ее государственной независимости (1991-2014 гг.). Результаты анализа показали, что на внутрирегиональном и межрегиональном уровнях снижается миграционная активность. Также снизилась интенсивность обмена населения между регионами страны. Вместе с тем, Украина за годы государственной независимости из-за депопуляционных процессов потеряла 6,5 млн. человек, а во внешних миграционных перемещениях населения потери составили свыше 1 млн. человек. Рассмотрена проблема нелегальной внешней трудовой миграции. Отмечено, что нелегальная миграция с Украины к угрозам национальной безопасности в Законе Украины «Об основах национальной безопасности Украины» не включена, и угрозу национальной безопасности со стороны нелегальной трудовой миграции с Украины органы государственной власти и управления как центральные, так и на местах недооценивают. Акцентировано внимание на том, что регулирование миграционных процессов на макроуровне должно стать весомой составляющей социальноэкономической политики государства, а мероприятия миграционной политики состоят в том, чтобы добиться упорядочения миграционного пространства страны и взять под контроль те миграционные процессы, которые в нем происходят. Сформулированы предложения, которые касаются перспективных и действенных мероприятий государственной миграционной политики Украины по упорядочению миграционного пространства, регулированию миграционного движения населения с позиций национальных приоритетов и региональных особенностей, а также личных потребностей мигрантов и предупреждения миграционных угроз национальной безопасности Украины. Определено, что в регулировании трудовых миграционных процессов решающая роль принадлежит управлению социально-экономическими факторами, то есть такими условиями жизни и трудовой деятельности людей, которые могут изменяться в результате перераспределения бюджетних средств, фонда зароботной платы, общественных норм потребления. 